[Entsyklopedija of edukation]. Kyiv: Yuricom Inter, 1040 p. [in Ukrainian].

2. Moskal, Yu. (2008). Svitovi tendentsii rozvitku zaochnoi ta distantsiynoi vishchoi osviti [World tendencies of the development correspondence and distance higher education]. Psychology and society, vol. 3, pp. 116-122. [in Ukrainian].

3. Kurliand, Z.N., Kheljuk, R.I. \& Semenova, A.V. et. al.; Kurliand, Z.N., (Ed.). (2007). Pedagogika vyshoji shkoly: navch. Posibnyk [Pedagogy of higher education: teach. guidances]. Kyiv: Znannia, 495 p. [in Ukrainian].

4. Selevko, G.K. (1998). Sovremennye obrazovatelnye tekhnologi [Modern educational technologies]. Moskov: Narodnoe obrasovanie:uchebnoe posobie, 256 p. [in Russian]. 5. Sysoev, P.V. (2012). Didakticheskie svoystva i funktsii sovremennykh informatsionnykh i kommunikatsionnykh tekhnologiy [Didactical features and functions of modern informational and communicational technologies]. Foreign languages at shool, vol. 6 . Moscow, pp. 12-21. [in Russian].

6. Osadchuk, O.L. (2009). Upravlenie samostoyatelnoy rabotoy studentov: metod. posobie [Management of the self-studying work of students: methodological guide]. Omsk: Publishing center KAN, 156 p. [in Russian].

Стаття надійшла до редакції 25.04.2018

УДК 378.011.3-051:373.2(73)

DOI:

Юрій Калічак, кандидат педагогічних наук, доиент кафедри загальної педагогіки та дошкільної освіти Дрогобииького державного педагогічного університету імені Івана Франка

\title{
ФОРМУВАННЯ КОМПЕТЕНТНОСТІ ВИХОВАТЕЛЯ ЗАКЛАДІВ ДОШКІЛЬНОЇ ОСВІТИ В ПРОЦЕСІ ПРОФЕСІЙНОЇ ПІДГОТОВКИ
}

У статті розглянуто проблему формування професійної компетентності фахівців дошкільної освіти; проаналізовано підходи до організації професійної підготовки педагогів; визначено складові частини професійної компетентності; обтрунтовано умови творчої самореалізації педагогів у галузі дошкільноі освіти з урахуванням новітніх підходів до виховання дітей дошкільного віку.

3'ясовано формування професійної компетентності педагогів передбачає не лише засвоєння дисциплін професійного ичклу, але $і$ знання сучасних концепцій дошкільної освіти, а саме компетентнісного, особистісноорієнтованого та діяльнісного підходів до організації освітнього процесу в закладах дошкільної освіти.

Ключові слова: формування професійної компетентності; умови творчої самореалізачії; професійна освіта; дошкільна освіта; вихователь дітей дошкільного віку.

Jim. 10.

Yuriy Kalichak, Ph. D.(Pedagogy), Associate Professor of the General Pedagogy and Preschool Education Department Drohobych Ivan Franko State Pedagogical University

\section{THE FORMATION OF COMPETENCE OF EDUCATOR OF INSTITUTIONS OF PRESCHOOL EDUCATION IN THE PROCESS OF PROFESSIONAL TRAINING}

The article analyzes the peculiarities of vocational training of preschool education specialists, the main priority of which is the combination of personal and activity approaches. A modern institution of higher pedagogical education should train a student who will work with children of preschool age, actively participate in social life, create conditions for the development of a person who can not only assess the situation and adapt to social changes, but also think in an original and non-standard way and generate and implement ideas, develop ways of positive transformation, initiative and autonomy, and creativity.

The etymology and meaning of the term "competence" have been clarified, which gives grounds to return in the interpretation of this definition to the European understanding of the most basic two meanings of the word: the legal and psychological ones, since nowadays there is no simple unambiguous interpretation on this issue.

It was found out that the professional competence of the pre-school educator involves a combination of professional and personal qualities necessary for successful pedagogical activity. A professionally competent teacher is the one who carries out the pedagogical activity and pedagogical communication at high level, and achieves continuously high results in teaching and upbringing of preschoolers.

The process of development of professional competence is characterized as a bloom of creative individuality, formation of susceptibility to pedagogical innovations, ability to adapt to changes in the pedagogical environment.

It has been proved that the formation of the professional competence of the future teacher of pre-school establishments occurs during the study at an institution of higher pedagogical education. It is important to choose such an institution, which would train the teachers with the necessary luggage of competencies. 


\section{ФОРМУВАННЯ КОМПЕТЕНТНОСТІ ВИХОВАТЕЛЯ ЗАКЛАДІВ ДОШКІЛЬНОӤ ОСВІТИ}

В ПРОЦЕСІПРОФЕСІЙНОӤПІДГОТОВКИ

The components of the professional competence, namely the key, basic and special ones, have been singled out.

Keywords: formation of professional competence; conditions of creative self-realization; the vocational education; the preschool education; a pre-school teacher.

П остановка проблеми. Сучасні цивілізаційні виклики передбачають кардинальні зміни в системі професійної освіти загалом. Завдяки діяльності педагога реалізується політика держави у створенні інтелектуального та духовного потенціалу нації, розвиток вітчизняної науки, техніки і культури. Формування національної системи освіти зумовлює потребу підготовки педагога нового покоління для всіх систем едукації, зокрема і для системи дошкільної освіти, у якій відбуваються зміни, пов'язані з оновленням iii змісту, перебудовою взаємодії у системі “вихователь-дошкільник”, появою нових різноманітних типів закладів дошкільної освіти. Інноваційні освітні напрями в системі дошкільної освіти потребують педагога нового типу i висувають надзвичайно високі вимоги до його професійної компетентності.

Тривалий і стабільний поступ у житті суспільства не можливий без зміни ставлення до формування справжніх професіоналів упершій та, безперечно, найважливішій ланці освіти дошкільній. Яким чином будуть сформовані у ранньому віці пізнавальні інтереси дитини, так вона і працюватиме над удосконаленням власного інтелекту - найбільшої цінності для усієї держави загалом. Підготовка компетентного, конкурентоспроможного фахівця для роботи в динамічно змінюваних умовах, здатного самостійно і творчо вирішувати професійні завдання, готового до постійної самоосвіти та самовдосконалення - основне завдання сучасної вищої освіти. Вирішення цієї проблеми передбачає створення якісно нового освітнього простору на сучасному етапі державотворення української нації.

Особистісно зорієнтована освітня парадигма потребує від вищої педагогічної школи досконалої підготовки майбутніх педагогів, зокрема фахівців у галузі дошкільної освіти. Сучасний вихователь дітей дошкільного віку змушений орієнтуватися в сучасних наукових досягненнях, в інноваціях психолого-педагогічної науки, повинен опановувати різноманітні новітні технології едукації дітей дошкільного віку, виробити здатність до саморозвитку, самовдосконалення i самопроектування в різних сферах життєдіяльності упродовж усього життя, насамперед професійного. У зв'язку з цим підвищення рівня професіоналізму майбутніх вихователів дітей дошкільного віку в процесі професійної підготовки у закладах вищої педагогічної освіти, які були б здатні плекати активну, самостійну, творчу особистість $є$ актуальністю сьогодення.

Проблема професійної компетентності педагогів широко вивчається в Україні (Л. Артемова [1], Г. Бєлєнька [2], О. Богініч [3], А. Богуш [4], Н. Гавриш [5], Н. Кічук [8] та інші) та за кордоном (Д. Равен, У. Хутмахер, Б. Оскарссон, М. Уоллес та ін.). Проблеми структури і змісту психолого-педагогічної та фахової підготовки майбутніх вихователів розглядали Г. Бєлєнька [2], О. Богініч [3], В. Нестеренко [9], I. Поніманська [3], Р. Пріма [3] та інші. Особливості професійної підготовки майбутніх фахівців дошкільної освіти спостерігаємо в дослідженнях А. Богуш [4], Т. Поніманської [10] та інші. Вказані дослідження забезпечили можливість розглянути зміст і технологію формування професійної компетентності фахівця в умовах ступеневої освіти.

Вченими визначено теоретико-методологічні основи підготовки майбутніх фахівців дошкільної освіти в сучасних умовах, доведено, що сутністю професійно-педагогічної підготовки є система змістовно-педагогічних і організаційнометодичних заходів, спрямованих на забезпечення готовності майбутнього педагога до педагогічної діяльності.

Мета статті - проаналізувати формування основних компетентностей вихователів закладів дошкільної освіти в процесі професійної підготовки, а також уточнити їхнє значення.

Виклад основного змісту статті. Професійнопедагогічна підготовка в словникових джерелах визначається як система організаційних $\mathrm{i}$ педагогічних заходів, що забезпечує формування в особистості професійної спрямованості, знань, умінь, навичок і професійної готовності [7, 12].

Серед важливих завдань вітчизняної освітньої системи - забезпечення високого рівню освіти на основі збереження іiі фундаментальності та відповідності актуальним і перспективним потребам особистості, суспільства і держави. Програма модернізації освіти закладає нові вимоги до вихователя ЗДО, тобто до його професійної компетентності.

Рівень вищої освіти громадян держави визначає поступ суспільства, яке формує соціальні потреби, актуалізуючи вирішальну роль системи 


\section{ФОРМУВАННЯ КОМПЕТЕНТНОСТІ ВИХОВАТЕЛЯ ЗАКЛАДІВ ДОШКІЛЬНОӤ ОСВІТИ ВПРОЦЕСІПРОФЕСИЙНОӤПЦДОТОВКИ}

вищої освіти на сучасному етапі державного розвитку. Вища освіта поступово перетворюється в глобальний фактор розвитку суспільства.

Сучасний студент має бути готовим до активної участі в соціальному житті, створювати умови для розвитку особистості, здатної не лише оцінювати ситуацію і адаптуватися до соціальних змін, але й оригінально та нестандартно мислити, генерувати і реалізувати ідеї, розробляти шляхи позитивних перетворень, проявляти ініціативу, творчість та креативність.

Вища освіта $\epsilon$ важливим соціальним інститутом, в якому формується система етичних цінностей і норм, гідне ставлення до іншої людини, до навколишнього середовища, що передбачає повагу до особистості, ii унікальності, поглядів, прав і свобод; дотриманні принципів демократії, справедливості, толерантності; взаєморозуміння між етнічними, релігійними, культурними групами, відмову від насильства, жорстокості і т. ін. Усі ці характеристики справедливо проектуються на професійну підготовку майбутнього дошкільного педагога, адже його професійна діяльність безпосередньо пов'язана з розвитком суспільства $[1,85]$.

На сьогоднішній день підготовка майбутніх фахівців дошкільної освіти розглядається вченими як багатофакторна структура, головне завдання якої полягає в набутті кожним студентом особистісного сенсу діяльності, формуванні професійної майстерності, постійно зростаючого інтересу до роботи 3 дітьми та їх батьками, а також у розвитку успішності в діяльності. Яскравим штрихом виокремлюється проблема вдосконалення форм організації навчального процесу, пошуку відповіді на питання про ефективні умови розвитку і самореалізації особистості в процесі опанування спеціальністю. Не втрачає актуальності питання перегляду змісту педагогічної освіти. Однак, за Н. Гавриш $[5,45]$, для вдосконалення професійно-педагогічної підготовки майбутніх фахівців недостатньо переглянути лише змістовий компонент. Важливо розробляти такі педагогічні технології, при яких стає можливим якісне засвоєння змістовного компоненту в поєднанні 3 індивідуальною творчою самореалізацією студента. Відзначимо, що грунтовно і комплексно проблему формування професійної компетентності сучасних вихователів дітей дошкільного віку розглянуто в працях В. Белєнької, яка визначає професійну компетентність як опрофесійну підготовленість і здатність суб'єкта праці до виконання завдань і обов'язків повсякденної діяльності. Вона зумовлена когнітивним i діяльнісним компонентами підготовки фахівця, виступає мірою і основним критерієм визначення його відповідності до умов праці $[2,35]$.

Для того, щоб здійснювати керівництво розвитком особистості, необхідно бути компетентним. У науковий обіг поняття “компетентність” увійшло відносно недавно. В кінці XX століття у вітчизняній науці з'явився новий напрям - компетентнісний підхід в освіті. Існуючі досі поняття, такі як “професіоналізм", “кваліфікація", “професійні здібності” та інші, було інтегровано в понятті “професійна компетентність”. На сьогоднішній день здійснено низку наукових досліджень, в яких 3 різних наукових позицій розглядається зазначене поняття $[2 ; 4 ; 5]$.

Компетентний: прикметник, запозичений в німецьку мову у XVIII столітті з латинської competens (-entis), дієприкметника I (теперішнього часу активного стану) дієслова competere “зустрічатися прагнути, законно вимагати, належати, підходити”.

Раніше - у XVI столітті - засвідчений (в німецькій мові) абстрактний іменник “компетенція" первинно означав “право на доходи".

Компетенція: через польське посередництво запозичено 3 латинської мови; латинське competentia - “відповідність, узгодженість" пов'язане 3 competere “разом домагатися, прагнути, сходитися, зустрічатися, відповідати, узгоджуватися" [6, $541-542]$.

У XV столітті французи утворили абстрактний іменник compétence, що був запозичений в англійську як competence (синонім його юрисдикція), а в XVI столітті - у німецьку абстрактний іменник Kompetenz.

Латинський іменник competentia - звідки, ясна річ, українська калька “компетенція” утворений так само - від дієприкметника competens. Якщо латинське competentia калькується в українській як “компетенція”, то інше українське слово “компетентність" - має інше походження, тобто - як калька французького субстантивованого іменника compétence.

Зважаючи на певне зміщення значень у французькому compétence в порівнянні $з$ його латинським оригіналом competentia, слід полишити простіше, менш комплексне і давніше значення першого слова українському термінові “компетенція” (“повноваження”), а друге українському термінові “компетентність” (“знання й уміння”).

Тлумачення обох цих слів у Словнику української мови таке: 


\section{ФОРМУВАННЯ КОМПЕТЕНТНОСТІ ВИХОВАТЕЛЯ ЗАКЛАДІВ ДОШКІЛЬНОЇ ОСВІТИ В ПРОЦЕСІПРОФЕСИЙНОӤПДГОТОВКИ}

Компетентний, а, е. 1. Який має достатні знання в якій-небудь галузі, з чим-небудь добре обізнаний, тямущий. // який грунтується на знанні, кваліфікований (у 2 значенні). 2. Який має певні повноваження, повновладний.

Компетентність. Властивість до значення компетентний.

Компетенція. 1. Добра обізнаність із чимнебудь. 2. Коло повноважень якої-небудь організації або особи.

Як видно, тут бракує ясності і критеріїв для розрізнення компетентності та компетенції (зважаючи на час компіляції словника, це не дивно).

Тому, слід повернутися до європейського розуміння найосновніших двох значень цього слова. Як подають романо-германськомовні словники, йдеться про два значення: юридичне й психологічне.

Приклад: дошкільна освіта входить до його компетенції як випускника соціальногуманітарного факультету, проте, йому бракує належної компетентності у виборі методів їі здійснення.

У дослідженнях сучасних вчених виокремлено кілька видів професійної компетентності, на яких грунтується зрілість фахівця в професійній діяльності. Так, відзначають, що:

- соціально-психологічна компетентність визначається як властивість індивіда ефективно взаємодіяти 3 людьми, які його оточують в системі міжособистісних взаємин (вміння орієнтуватися в соціальних ситуаціях, обирати адекватні способи спілкування);

- комунікативна компетентність полягає в поєднанні знань, невербальних умінь і навичок спілкування;

- професійно-педагогічна компетентність розглядається як здатність до продуктивного спілкування в умовах, які визначені існуючою педагогічною системою [2, 87-90].

Вказані основні елементи професійної компетентності в ході науково-педагогічної підготовки майбутнього дошкільного педагога вимагають уточнень відповідно до особливостей його професійної діяльності.

Професійна компетентність - здатність успішно діяти на основі практичного досвіду, вміння і знань при вирішенні професійних завдань. Професійна компетентність вихователя передбачає сукупність професійних і особистісних якостей, необхідних для успішної педагогічної діяльності. Професійно компетентним можна назвати вихователя, який на досить високому рівні здійснює педагогічну діяльність, педагогічне спілкування, досягає стабільно високих результатів у навчанні та вихованні дошкільників $[2 ; 4 ; 5]$.

Розвиток професійної компетентності - це розвиток творчої індивідуальності, формування сприйнятливості до педагогічних інновацій, здібностей адаптуватися до змін у педагогічному середовищі. Від професійного рівня педагога безпосередньо залежить соціально-економічний і духовний розвиток суспільства.

Формування професійної компетентності майбутнього вихователя закладів дошкільної освіти формується під час навчання студента у закладі вищої педагогічної освіти. Важливо обрати такий заклад вищої освіти, який би готував затребуваних педагогів 3 необхідним багажем компетентностей. Але важливо й те, які компетентності необхідні в професійній діяльності вихователя закладів дошкільної освіти.

Виокремимо складові компоненти професійної компетентності, а саме ключові, базові та спеціальні.

Під ключовими компетентностями розуміють здатності вирішувати професійні завдання на основі використання інформації, комунікації, соціально-правових основ поведінки особистості в громадянському суспільстві. Базові компетентності - це сукупність універсальних і предметно-спеціалізованих компетентностей, що відображають специфіку певної професійної педагогічної діяльності. Спеціальні компетенції $€$ результатом інтеграції ключових і базових, що необхідні для реалізації професійної діяльності в конкретній галузі. Отже, ключові, базові та спеціальні компетенції, взаємодіючи один з одним, виявляються в процесі вирішення життєво важливих професійних завдань різного рівня складності в різних контекстах. Всі три види повинні формуватися одночасно, що забезпечить становлення професійної компетентності майбугнього вихователя закладів дошкільної освіти [5].

Висновки. Грунтовний аналіз підходів до організації освітнього процесу в закладах вищої педагогічної освіти дозволяє стверджувати, що в умовах успішної творчої самореалізації майбутніх фахівців дошкільної сфери є комплексний підхід до формування професійної компетентності педагогів, яка передбачає не лише засвоєння дисциплін професійного циклу, але і знання сучасних концепцій дошкільної освіти, а саме компетентнісного, особистісно орієнтованого та діяльнісного підходів до організації освітнього процесу в закладах дошкільної освіти і вміння реалізовувати ці знання на практиці, творчо поєднуючи і організовуючи їх. 


\section{ФОРМУВАННЯ КОМПЕТЕНТНОСТІ ВИХОВАТЕЛЯ ЗАКЛАДІВ ДОШКІЛЬНОЇ ОСВІТИ ВПРОЦЕСІПРОФЕСИЙНОӤПІДГОТОВКИ}

\section{ЛІТЕРАТУРА}

1. Артемова Л. В. Модель ступеневої підготовки фахівця дошкільної освіти у вищих навчальних закладах / Л. В. Артемова, Ю. М. Косенко // Психологопедагогічні проблеми підготовки вчительських кадрів в умовах трансформації суспільства. Матеріали міжнар. наук.-теор. конф. до 80-ї річниці НПУ ім. М. П. Драгоманова. 2000. - Вип. 1. - С. 84-86

2. Бєлєнька Г. В. Формування професійної компетентності сучасного вихователя дошкільного навчального закладу: монографія / Ганна Володимирівна Бєлєнька. - К.: Університет, 2011. $-320 \mathrm{c}$.

3. Богініч О.Л., Борисова О.Л., Загарницька I.I. Підготовка вихователя до розвитку особистості дитини в дошкільному віці: монографія / О.Л.Богініч, 3.Н.Борисова, І.І.Загарницька та ін.; за заг. Ред. I.І.Загарницької.- К.: Вид-во НПУ імені М.П.Драгоманова, 2009. - 310 с.

4. Богуш А. М. Компетентнісний підхід у підготовці майбутніх фахівців дошкільної освіти у вищому навчальному закладі / А. М. Богуш // Реалізація європейського досвіду компетентнішого підходу у вищій школі України: матеріали метод, семінару (НАПН України, Інститут педагогіки НАПН України). - К.: Педагогічна думка, 2009. - C. 271-281.

5. Гавриш Н.В. Орієнтація на розвиток суб'єктності студента у процесі підготовки професійно компетентних фахівців 3 дошкільної освіти / Н.В. Гавриш, О.Н. Сущенко // Педагогічні науки : зб. наук. праць Бердян. держ. пед. ун-ту. - Бердянськ, 2007. - Вип. 3. - С. 44 - 49.

6. Етимологічний словник української мови: У 7 тт., К., 1982 - 2005. - 572 с.; Т. 2, С. 541 - 542.

7. Желєзнова Л.Б. Професійна підготовка педагога-вихователя [Електронний ресурс] / Л.Б. Желєзнова. - Режим доступу: http: // bank.orenipk.ua.

8. Кічук Н. В. Технологізація професійної підготовки вихователя дошкільного закладу освіти: деякі аспекти проблеми/Надія Василівна Кічук // Науково-практичний журнал "Наука і освіта"- О., 2014. - № 10. - С.87-89.

9. Нестеренко В. В. Теоретико-методологічні засади підготовки майбутніх фахівців дошкільної освіти в системі заочного навчання:[монографія] / В.В. Нестеренко.- Одеса: Видавництво ТОВ “Лерадрук”, 2012. - 399 с.

10. Підготовка фахівців з дошкільної освіти за кредитно-модульною системою організації навчального процесу: [навч.-метод. посібник] / за ред. Т. Поніманської. - К.: Міленіум, 2007. 244 c.

\section{REFERENCE}

1. Artemova, L.V. \& Kosenko, Yu.M. (2000). Model stupenevoi pidhotovky fakhivtsya doshkilnoyi osvity u vyshchykh navchalnykh zakladakh [A model of a phased training of specialist in pre-school education in higher educational institutions]. Psykholohopedahohichni problemy pidhotovky vchytelskykh kadriv $v$ umovakh transformatsiyi suspilstva. materialy mizhnar. nauk.-teor. konf. do 80-yi richnytsi NPU im. M. P. Drahomanova Psychological and pedagogical problems of teacher training in the conditions of societys transformation. Proceedings of International Scientific Conference to the 80th anniversary of the M. Drahomanov National Pedagogical University. (pp.84-86). Issue 1. [in Ukrainian].

2. Belenka, G.V. (2011). Formuvannya profesiynoyi kompetentnosti suchasnoho vykhovatelya doshkilnoho navchalnoho zakladu [Formation of professional competence of modern educator of preschool educational institution]. Kyiv: University, 320 p. [in Ukrainian].

3. Bohynych, O., Borysova, O.L. \& Zaharnytska, I. I. et al. (2009). Pidhotovka vykhovatelya do rozvytku osobystosti dytyny $v$ doshkilnomu vitsi [Teaching the educator to develop the child's personality in preschool age]. Kyiv: Publ., of the M. Drahomanov NPU, 310 p. [in Ukrainian].

4. Bohush, A. M (2009). Kompetentnisnyy pidkhid u pidhotovtsi maybutnikh fakhivtsiv doshkilnoyi osvity u vyshchomu navchalnomu zakladi [A Competency Approach in Training Specialists in Pre-School Education at a Higher Educational Institution]. Realizatsiya yevropeyskoho dosvidu kompetentnishoho pidkhodu u vyshchiy shkoli Ukrayiny [Implementation of the European experience of a more competent approach in higher education in Ukraine: materials method]. Seminar (NAPS of Ukraine, Institute of Pedagogy, National Academy of Sciences of Ukraine). Kyiv: Pedagogical thought, pp. 271-281. [in Ukrainian].

5. Havrysh, N.V. \& Sushchenko, O.N. (2007). Oriyentatsiya na rozvytok subyektnosti studenta u protsesi pidhotovky profesiyno kompetentnykh fakhivtsiv z doshkilnoyi osvity [Focus on the development of student subjectivity in the training of professionally competent specialists in preschool education]. Pedagogical sciences: Berdyansk, vol. 3, pp. $44-49$. [in Ukrainian].

6. Etymolohichnyy slovnyk ukrayinskoyi movy (1982). [An etymological dictionary of the Ukrainian language]: In 7 vols., Kyiv, 1982 - 2005; 572 pp.; Vol. 2, pp. 541 - 542. [in Ukrainian].

7. Zheleznova, L. B. Profesiyna pidhotovka pedahoha-vykhovatelya [Professional training of a 
teacher-educator]. [Electronic resource]. Access mode: http: // bank.orenipk.ua. [in Ukrainian].

8. Kichuk, N.V. (2014). Tekhnolohizatsiya profesiynoyi pidhotovky vykhovatelya doshkilonoho zakladu osvity: deyaki aspekty problemy [Technological training of the teacher of a preschool educational institution: some aspects of the problem]. Scientific and practical journal "Science and Education”. No. 10, pp. 87-89. [in Ukrainian].

9. Nesterenko, V.V. (2012). Teoretykometodolohichni zasady pidhotovky maybutnikh fakhivtsiv doshkilnoyi osvity $v$ systemi zaochnoho navchannya [Theoretical and methodological principles of training specialists in preschool education in the system of correspondence studies]. Odessa: Publishing LLC "Leradruk", 399 p. [in Ukrainian].

10. Ponimanskaya,T. (Ed.). (2007). Pidhotovka fakhivtsiv z doshkilnoyi osvity za kredytnomodulnoyu systemoyu orhanizatsiyi navchalnoho protsesu [Training specialists in preschool education under the credit module system of educational process organization]. Teaching method. Manual. Kyiv: Millennium, 244 p. [in Ukrainian].

Стаття надійшла до редакції 08.05.2018

\title{
УДК 378.1.61
}

DOI:

Камілла Магрламова, кандидат педагогічних наук, викладач кафедри мовної підготовки ДЗ “Дніпропетровська медична академія МОЗ України”

\begin{abstract}
АНАЛІЗ СИСТЕМИ КВАЛІФІКАЦІЙ МАЙБУТНІХ ЛІКАРІВ У ВЕЛИКІЙ БРИТАНІЇ
Вища система освіти Великої Британії є одна з найунікальніших та найскладніших з усіх які існують нетільки в країнах Європи, але в вусьому світі. Комплексна загальна система кваліфікаційта навчальних програм демонструють прозорість та полегшують мобільність персоналута студентів. Рівень автономії вищих навчальних закладів Великоі Британії самий високий порівняно з подібними установами в інших країнах. Більшеніж 150 вищих навчальних закладів та кількість студентів в окремих університетах та коледжах коливається від 500 до більи ніж 150000.

Відмічено, щчо невід 'ємними складовими системи забезпечення якості професійної освіти та навчання у Великій Британії є національні стандарти кваліфікацій, щзо базуються на національних професійних стандартах; національна рамка кваліфікацій, рівні якої описані у термінах залікових одиниць. У вищій освіті регулювання кваліфікацій ВНЗ здійснюють за допомогою спечіального документу “Академічна інфраструктура”, який містить: рамки кваліфікацій вищої освіти Англії, Уельсу, Північної Ірландії Шотландї; академічні стандарти з різних галузей знань, у яких описані очікувані результати засвоєння дисциилін, в тому числі уміння та рівень розвитку здібностей, компетениії, специифікацію програм навчання.

Ключові слова: вищі навчальні заклади; кваліфікації; майбутні лікарі; професійна освіта; система освіти. Лim. 10.
\end{abstract}

Kamilla Mahrlamova, Ph.D.(Pedagogy), Leacturer of the Language Training Department State Establishment "Dnipropetrovsk Medical Academy of the Ministry of Health of Ukraine"

\section{THEANALYSIS OFTHE QUALIFICATIONALSYSTEM OF FUTURE DOCTORS INTHE UK}

The UK's higher education system is one of the most unique and complex of all that exists not only in Europe but also throughout the world. A comprehensive system of qualifications and training programs demonstrates transparency and facilitates mobility of staff and students. The level of autonomy of higher education institutions in Great Britain is the highest compared to similar institutions in other countries. More than 150 higher education institutions and the number of students in individual universities and colleges ranges from 500 to more than 150,000.

It is noted that the national qualifications standards based on national professional standards are integral parts of the quality assurance system for vocational education and training in the UK; the national framework of qualifications, the levels of which are described in terms of score units. In higher education, the regulation of qualifications of higher educational establishments is carried out with the help of a special document "Academic Infrastructure", which contains. the framework of qualifications of higher education in England, Wales, Northern Ireland and Scotland; academic standards in various fields of knowledge, which describe the expected outcomes of mastering disciplines, including skills and the level of development of abilities, competencies, specification of training programs.

Keywords: higher educational establishments; qualifications; the future doctors; the vocational education; the educational system.

П

остановка проблеми. По всій Великій Британії відповідальним органом за встановлення стандартів

та моніторинг на кожному етапі медичної освіти та навчання є Генеральна медична рада (GMC), котра також здійснює нагляд за постійним 